in these patients, and lower doses of dipyridamole had a proportionately lesser effect on the improvement of platelet survival. Aspirin appeared to have a potentiating effect on dipyridamole, however, in that $1 \mathrm{~g}$, combined with $100 \mathrm{mg}$ of dipyridamole daily in a single dose instead of $400 \mathrm{mg}$ in divided doses, prevented valvular platelet consumption. We decided to assess this synergistic effect of the combined drug regimen on the in-vitro platelet reactions before and after general surgery (the results of which will be reported elsehwere) and on the incidence of postoperative DVT, which is initiated by the adhesion of platelets to damaged vascular endothelium, followed by platelet aggregation to form a platelet mass. This mass is then consolidated by the deposition of fibrin.

The dipyridamole and aspirin regimen has several attractive features. Firstly, the drugs are simple to administer and even if the patient is on nasogastric suction the tablets can be crushed and dissolved and given through the tube, the suction being turned off for two hours. Repeated platelet function studies before and after administration of the drugs showed that, no matter which technique was used, a definite effect on the platelet functions was achieved. Secondly, the potentiation of the action of dipyridamole by aspirin meant that the dose of dipyridamole could be reduced to $100 \mathrm{mg}$, and yet a considerable effect on platelet function was still detected. This greatly reduced the hypotensive and other side effects of the drug, which caused a $25 \%$ rejection rate in Browse and Hall's trial. No patient in our series had side effects that could be attributed to dipyridamole and there were no complications that could be attributed to the use of the drug combination.

The administration of low-dose subcutaneous heparin has been successful in preventing postoperative thromboembolism. ${ }^{26}{ }^{27}$ But more recently Evarts and Alfidi ${ }^{28}$ reported that the administration of low-dose subcutaneous heparin did not afford protection for patients undergoing hip surgery.

The regimen of antiplatelet drugs described (aspirin and dipyridamole) shows promise of being an effective and simple method of reducing the incidence of postoperative DVT. It is easy to administer and no complications have so far been noted.

We thank Professor R C Bennett for his advice and helpful criticism, Miss Maria Connell, our technician, for her tireless work and help, and
Boehringer Ingelheim for their generous support. The study into the diagnosis and prevention of thromboembolic disease has been supported by grants from the National Health and Medical Research Council, and the Lfe Insurance Medical Research Fund of Australia and New Zealand.

\section{References}

1 Virchow, R, Beitraege zur Experimentellen Pathologie und Physiologie, $1846,2,1$.

${ }^{2}$ Flanc, C, Kakkar, V V, and Clarke, M B, British fournal of Surgery, $1968,55,742$.

${ }^{3} \mathrm{Kakkar}, \mathrm{V}$ V, et al, Lancet, 1970, 1, 540.

${ }^{4}$ Horowitz, R E, and Tatter, D, in Thrombosis, ed S Sherry, K M Brinkhouse, and E Genton, p 19. Washington, National Academy of Sciences, 1969.

ed S Sherry, K M Brinkhouse, and E Genton, p 19.

${ }^{5}$ Mustard, J F, et al, Thrombosis et Diathesis Haemorrhagica, 1966, 21, suppl 131.

${ }^{6}$ Bygdeman, S, Eliasson, R, and Johnson, S-R, Lancet, 1966, 1, 1301.

${ }^{7}$ Negus, D, Pinto, D J, and Brown, N, Lancet, 1969, 1, 220.

${ }^{8}$ Flute, $\mathrm{P}$ T, et al, in Thromboembolism: Diagnosis and Treatment, ed V V Kakkar and A J Jouhar, p 69. Edinburgh, Churchill Livingstone, 1972.

${ }^{9}$ McLachlin, J, and Paterson, J C, Surgery, Gynecology and Obstetrics, 1951, 93, 1 .

10 Sevitt, S, and Gallagher, N, British fournal of Surgery, 1961, 48, 475.

11 Sevitt, S, Proceedings of the Royal Society of Medicine, 1975, 68, 261.

${ }^{12}$ Nicolaides, A N, Kakkar, V V, and Renney, J T G, British fournal of Surgery, 1971, 58, 307.

${ }_{13}$ Clayton, S, and Cross, M J, fournal of Physiology, 1963, 169, 82P.

${ }^{14}$ Mustard, J F, and Packham, M A, Pharmacology Review, 1970, 22, 97.

${ }^{15}$ Emmons, P R, et al, Lancet, 1965, 2, 603.

${ }^{16}$ Sullivan, J M, Harken, D E, and Gorlin, R, New England fournal of Medicine, 1971, 284, 1391.

17 Salzmann, E W, Harris, W H, and De Sanctis, R W, New England Fournal of Medicine, 1971, 284, 1287.

${ }^{18}$ Evans, G, et al, fournal of Experimental Medicine, 1968, 128, 877.

${ }^{19}$ Kakkar, V V, et al, American fournal of Surgery, 1970, 120, 527.

20 Kakkar, V V, et al, Lancet, 1969, 2, 230.

${ }^{21}$ Scharrer, I. Schepping, M, and Breddin, K, Klinische Wochenschrift, 1969, 47, 1318.

22 Butterfield, W H J, et al, Lancet, 1972, 2, 441.

${ }^{23}$ O'Brien, J R, Modern Concepts of Cardiovascular Disease, 1973, 42, 11.

24 Browse, N L, and Hall, J H, Lancet, 1969, 2, 718.

${ }^{25}$ Harker, L A, and Slichter, S J, New England fournal of Medicine, 1970, 183,1302 .

${ }^{26}$ Kakkar, V V, et al, Lancet, 1971, 2, 669.

27 Gallus, A S, et al, New England fournal of Medicine, 1973, 288, 545.

${ }^{28}$ Evarts, C M, and Alfidi, R J, fournal of the American Medical Association, $1973,225,515$.

\title{
Factor-VIII-related antigen: measurement by enzyme immunoassay
}

\author{
A BARTLETT, K M DORMANDY, C M HAWKEY, P STABLEFORTH, A VOLLER
}

British Medical fournal, 1976, 1, 994-996

\section{Summary}

Factor-VIII-related antigen was measured, both by an enzyme immunoassay using a microplate method and by

Nuffield Institute of Comparative Medicine, Zoological Society of London, London NW1 4RY

A BARTLETT, PHD, research assistant

C M HAWKEY, PHD, head of department of haematology

A VOLLER, DSC, senior lecturer in clinical tropical medicine, London School of Hygiene and Tropical Medicine

Haemophilia Centre, Royal Free Hospital, London NW3 2QG

K M DORMANDY, MD, reader in haematology and director of haemophilia centre

P STABLEFORTH, MB, BS, senior registrar in haematology the Laurell technique, in normal people, patients with von Willebrand's disease, haemophiliacs, and obligatory haemophilia carriers. The enzyme immunoassay was simpler to perform and gave equally reliable and reproducible results. Many more assays could be carried out at any one time.

\section{Introduction}

Antisera produced by immunising rabbits with human factor VIII precipitates with a protein known as the factor-VIII-related antigen. In normal people factor VIII clotting activity and factor-VIII-related antigen are present to the same extent; in patients with haemophilia there is a deficiency of the clotting activity but the antigen levels are normal, and in most cases of von Willebrand's disease both the clotting activity and the 
antigen are reduced in parallel. The finding that the ratio of clotting activity to antigenic material is decreased in haemophilia carriers $^{1}$ has improved the means of identifying the carrier state with a consequent increase in the demand for measurement of the factor-VIII-related antigen. Of the various immunological methods available for measuring factor-VIII-related antigen Laurell immunoelectrophoresis ${ }^{2}$ and radioimmunoassay ${ }^{3}$ are receiving the most attention. The former is time consuming, and the latter is restricted to laboratories with highly sophisticated personnel and equipment. Studies to assess the usefulness of enzyme-linked immunosorbent assays (ELISA) ${ }^{45}$ in various fields of clinical practice are in progress. This report deals with the preliminary findings using such an enzyme immunoassay to measure factor-VIII-related antigen.

\section{Materials and methods}

Plasma samples were tested from 20 normal people, 30 patients with von Willebrand's disease, 10 haemophiliacs, and 8 obligatory haemophilia carriers. Blood was collected into a polystyrene pot containing one-ninth volume of $3.8^{\prime \prime}{ }_{0}$ trisodium citrate. Factor VIII clotting assays were performed on fresh platelet-poor plasma by the method of Biggs $e t a^{6}$ using the Hyland factor VIII standard. Factor-VIII-related antigen was measured in frozen plasma samples by the micromodification of the enzyme immunoassay" and by the Laurell technique. The same frozen plasma standard, from a pool of 12 normal donors aged between 20 and 50 years, was used in both methods.

\section{ENZYME IMMUNOASSAY}

Principle-(1) A rabbit antibody to human factor VIII is adsorbed on to a polystyrene surface and excess, unadsorbed material is washed away. (2) A dilution of the test plasma is added, and "antigen" in the test plasma will be "captured" by the adsorbed antibody. Non-reactive material is washed away. (3) An enzyme-labelled rabbit antibody to factor VIII (conjugate) is added, which will attach to any factor VIII antigen fixed by the first layer of antibody. After incubation the excess conjugate is washed away. (4) The enzyme substrate is added. The rate of hydrolysis of the enzyme substrate is proportional to the amount of fixed conjugate and thus to the amount of factor-VIII-related antigen in the test plasma.

Technique-The immunoglobulin fraction of a commercially available rabbit antiserum to factor VIII was separated by precipitation with sodium sulphate. It was diluted to $100 \mu \mathrm{g}$ protein per $\mathrm{ml}$ in $0.05 \mathrm{M}$ carbonate buffer $\mathrm{pH} 9.6 ; 200 \mu \mathrm{l}$ amounts were added to each well of microhaemagglutination plates (Cooke Microtiter plates M29/AR Dynatech Laboratories). After incubation overnight at $4 \mathrm{C}$ the plates were washed three times in phosphate-buffered saline $\mathrm{pH}$ 7.4 containing $0.05^{\circ}$ polysorbate 20 (PBS polysorbate 20), excess fluid was shaken off, and the plates were used immediately. Test plasmas were diluted 1/10 in PBS polysorbate 20; duplicate $200 \mu \mathrm{l}$ samples were added to the plates and incubated for two hours at room temperature. The plates were washed as before, and then $200 ; \mu l$ of the conjugate (an aliquot of the immunoglobulin fraction of the rabbit antiserum to factor VIII, conjugated to alkaline phosphatase ${ }^{4}$ ) diluted $1 / 200$ in PBS polysorbate 20 was added to each well. The plates were incubated for two hours at room temperature and then washed as before, and $200 \mu$ of the enzyme substrate solution ( $1 \mathrm{~g} p$-nitrophenyl phosphate/l in $1 \mathrm{M}$ diethanolamine buffer $\mathrm{pH} 9.8$ ) was added to each well. The enzyme substrate reactions were stopped by adding $50 \mathrm{ul}$ $3 \mathrm{M} \mathrm{NaOH}$ when the absorbence at $400 \mathrm{~nm}$ of the reference plasma standard reached 1.0 , and this was taken as $100^{\circ}{ }_{0}$. The results are expressed as a percentage of the reference standard.

\section{LAURELL IMMUNOASSAY}

Factor VIII antigen was measured by the Laurell technique as modified by Stableforth et al. ${ }^{7}$ The results were expressed as a percentage of the reference standard.

\section{Results}

The correlation between the results obtained by the enzyme immunoassay and the Laurell technique is shown in the fig. The

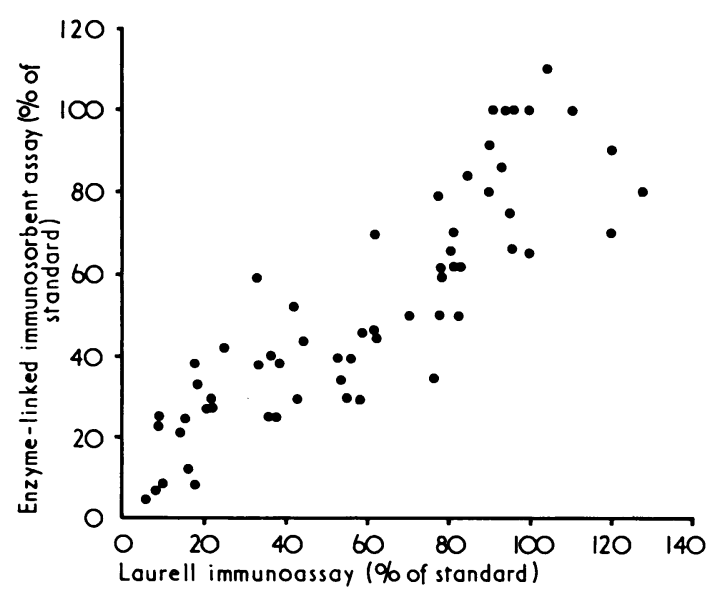

Correlation between enzyme immunoassay and Laurell immunoassay for determination of factor-VIII-related antigen. (Plasma samples from 20 normal people, 30 patients with von Willebrand's disease, and 10 haemophiliacs were tested.)

TABLE I-Range of values for factor-VIII-related antigen in three groups tested expressed as percentage of reference standard plasma

\begin{tabular}{|c|c|c|}
\hline & Enzyme immunoassay & Laurell immunoassay \\
\hline $\begin{array}{llll}\begin{array}{l}\text { Normal people } \\
\text { Haemophiliacs }\end{array} & \ldots & \ldots & \ldots \\
\begin{array}{l}\text { Patients with von } \\
\text { disease }\end{array} & \text { Willebrand's } & \ldots \\
\begin{array}{llll}\text {. . } & \ldots & \ldots\end{array}\end{array}$ & $\begin{array}{r}34-100^{\circ} \\
62-110 \% \\
<10-60 \%\end{array}$ & $\begin{array}{r}62-134{ }^{\circ} \\
81-115 \% \\
<10-78 \%\end{array}$ \\
\hline
\end{tabular}

TABLE II-Clotting activity and factor VIII antigen measurements by both methods in obligatory haemophilia carriers

\begin{tabular}{|c|c|c|c|c|c|}
\hline \multirow{2}{*}{$\begin{array}{l}\text { Obligatory } \\
\text { carrier }\end{array}$} & \multirow{2}{*}{$\begin{array}{c}\text { Factor } \\
\text { VIII } \\
\text { clotting } \\
\text { activity } \\
\left({ }^{\circ}, 0\right)\end{array}$} & \multicolumn{2}{|c|}{ Factor VIII antigen } & \multicolumn{2}{|c|}{$\begin{array}{l}\text { Ratio of factor VIII } \\
\text { clotting activity to } \\
\text { factor VIII antigen }\end{array}$} \\
\hline & & $\begin{array}{c}\text { Enzyme } \\
\text { immunoassay } \\
\left({ }^{(}{ }^{\prime}\right)\end{array}$ & $\begin{array}{c}\text { Laurell } \\
\text { immunoassay } \\
\left({ }^{\circ}, 1\right)\end{array}$ & $\begin{array}{c}\text { Enzyme } \\
\text { immunoassay }\end{array}$ & $\begin{array}{c}\text { Laurell } \\
\text { immunoassay }\end{array}$ \\
\hline $\begin{array}{l}1 \\
2 \\
3 \\
4 \\
5 \\
6 \\
7 \\
8\end{array}$ & $\begin{array}{r}20 \\
8 \\
76 \\
55 \\
59 \\
27 \\
64 \\
48\end{array}$ & $\begin{array}{r}59 \\
85 \\
120 \\
92 \\
100 \\
90 \\
114 \\
90\end{array}$ & $\begin{array}{r}50 \\
105 \\
113 \\
88 \\
102 \\
71 \\
120 \\
115\end{array}$ & $\begin{array}{l}0.34 \\
0.09 \\
0.60 \\
0.60 \\
0.60 \\
0.30 \\
0.60 \\
0.50\end{array}$ & $\begin{array}{l}0.40 \\
0.07 \\
0.68 \\
0.60 \\
0.60 \\
0.40 \\
0.50 \\
0.40\end{array}$ \\
\hline
\end{tabular}

ranges of values for the controls, haemophiliacs, and patients with von Willebrand's disease are shown in table I. The ratio of clotting activity to factor-VIII-related antigen for the obligatory haemophilia carriers was calculated using both the enzyme immunoassay and the electrophoresis results; the assay values and ratios are shown in table II.

\section{Discussion}

The correlation between factor-VIII-related antigen results by the two methods was good. When taken in conjunction with the factor VIII clotting activity the diagnostic significance of the factor-VIII-related antigen was equally satisfactory in the two methods.

The enzyme immunoassay gives reproducible results and, by means of a reference standard, values may be interpreted in absolute units. The assay is sensitive, easy to perform, and employs stable, safe, and relatively cheap reagents. The microplate modification is suitable for large-scale use, and the only requirement in terms of equipment is a simple spectrophoto- 
meter. Our preliminary results indicate that the method is suitable for measuring factor-VIII-related antigen. The method may well have other haematological applications.

This work was aided by a grant from the Ernest Kleinwort Charitable Trust. We also thank Pakaimas Bintadish, Josephine Berney, Elaine Chescoe, and the staff of the Haemophilia Centre laboratory for technical help. The Haemophilia Centre is designated as an International Haemophilia Training Centre by the World Federation of Haemophilia.

\section{References}

1 Zimmerman, T S, Ratnoff, O D, and Littell, A S, fournal of Clinical Investigation, 1971, 50, 255

${ }^{2}$ Laurell, C B, Analytical Biochemistry, 1966, 15, 45.

${ }^{3}$ Hoyer, L W, Fournal of Laboratory and Clinical Medicine, 1972, 80, 822.

${ }^{4}$ Engvall, E, and Perlmann, P, fournal of Immunology, 1972, 109, 129.

5 Voller, A, et al, Lancet, 1975, 1, 426.

6 Biggs, R, Eveling, J, and Richards, G, British fournal of Haematology, $1955,1,20$.

7 Stableforth, P, et al, fournal of Clinical Pathology, 1975, 28, 498.

\section{SHORT REPORTS}

\section{Meningitis due to relatively penicillin-resistant pneumococcus}

Until recently pneumococci have been regarded as invariably sensitive to benzylpenicillin, but several recent reports have described resistant strains. ${ }^{1-5}$ We report here a case of meningitis due to a penicillinresistant Pneumococcus.

\section{Case report}

A 10-month-old Oxfordshire girl presented with meningitis in December 1974 after one day's illness. Cerebrospinal fluid had $2 \cdot 5 \cdot 10^{9} / 1\left(2500 / \mathrm{mm}^{3}\right)$ white cells, predominantly polymorphs, and Gram-positive diplococci were seen in the smear. She was treated immediately with $300 \mathrm{mg}$ benzylpenicillin given intravenously every six hours. The pneumococci isolated were initially reported as sensitive to penicillin, sulphonamide, chloramphenicol, erythromycin, and lincomycin and resistant to tetracycline, using antibiotic discs. Despite an initial improvement, the child's clinical condition deteriorated on the fourth day and the dose of penicillin was therefore increased to $600 \mathrm{mg}$ four-hourly $(360 \mathrm{mg} / \mathrm{kg} /$ day). A further CSF specimen taken on the eighth day showed $4.75 \times 10^{9}$ white cells $1\left(4750 / \mathrm{mm}^{3}\right)$ and pneumococci were still present. A review of the original antibiotic sensitivities showed that the zone of inhibition around the 1-unit penicillin disc was diminished compared with zone sizes produced by random control strains. The strain appeared to be fully sensitive to a $25-\mu \mathrm{g}$ ampicillin disc, and as a report had indicated that pneumococci relatively resistant to penicillin were sometimes sensitive to ampicillin, ${ }^{2}$ ampicillin $500 \mathrm{mg}$ was given six-hourly $(200 \mathrm{mg} / \mathrm{kg})$ instead of penicillin. The patient improved immediately and all subsequent CSF specimens showed a progressive fall in white cell count and were sterile. Gentamicin $(30 \mathrm{mg}$ ) was given intravenously each day during the last two days of treatment with penicillin and for the first four days of the course of ampicillin but is unlikely to have influenced the therapeutic result because of its poor penetration into the CSF. The child was well when discharged home on the 13th day and has remained so.

Family history-The patient's father and her 5-year-old brother had recently suffered from upper respiratory infections. The patient had not received penicillin before admission to hospital, but four weeks previously her brother had received penicillin drops for an ear infection. A few days after the girl left hospital a 6-month-old boy who lived in the neighbourhood was admitted to hospital with convulsions, but meningitis was excluded. Both families were in close social contact.

Further investigations-Nose and throat swabs were taken from all members of the girl's family and from the boy neighbour and cultured for pneumococci. Multiple colonies from each positive culture were serotyped, and the minimum inhibitory concentrations (MICs) of penicillin, ampicillin, cloxacillin, and cephalothin for all strains were determined by the plate dilution method, using a multipoint inoculator (table).

The MIC of penicillin for the patient's CSF strain was 0.31-0.62 units $/ \mathrm{cm}^{3}$ $(0 \cdot 19-0 \cdot 37 \mu \mathrm{g})$ and the MIC of tetracycline was $12.5 \mu \mathrm{g} / \mathrm{cm}^{3}$.

\section{Discussion}

Three strains of pneumococci relatively resistant to penicillin were isolated in Australia in 1967-70, and during the same period $12^{\circ}{ }_{0}^{\circ}$ of 530 pneumococci isolated in New Guinea were similarly resistant, with MICs ranging from $0 \cdot 1$ to $2 \cdot 0 \mu \mathrm{g} / \mathrm{cm}^{3} .^{1-3}$ A penicillin-resistant pneumococcus has been isolated from sputum in Alberta, Canada, with MIC values almost identical to those obtained for the present CSF strain. In the USA a case of meningitis due to a penicillinresistant pneumococcus has been reported in a 3-year-old boy with sickle cell anaemia who was cured with a 27-day course of benzylpenicillin $(600 \mathrm{mg} / \mathrm{kg}){ }^{5}$ No similar resistant strains appear to have been recorded in Britain.

The reasons for therapeutic success in our patient are not clear, and it is unfortunate that antibiotic levels in the CSF were not measured. It is not convincingly explained by a difference in MIC, and ampicillin may have penetrated the blood-brain barrier better than penicillin in this case. The source of the penicillin-resistant strain was not discovered. Pneumococcal meningitis is unusual at this age, and at any age is usually a complication of a pre-existing infection such as otitis media or pneumonia, both of which were excluded in our patient.

We thank Dr B D Bower, consultant paediatrician, Oxford Area Health Authority, under whose care the patient was admitted; Dr M T Parker, Streptococcus Reference Laboratory, Colindale, for typing the strains and for helpful comments; and R Ebbs, for technical help.

${ }^{1}$ Hansman, D, and Bullen, M M, Lancet, 1967, 2, 264.

2 Hansman, D, Devitt, L, and Riley, I, British Medical fournal, 1973, 3, 405

${ }^{3}$ Hansman, D, et al, Medical fournal of Australia, 1974, 2, 353

4 Dixon, J M S, Lancet, 1974, 2, 474.

5 Naraqi, S, Kirkpatrick, G P, and Kabins, S, fournal of Paediatrics, 1974, 85,671 .

Departments of Paediatrics and Pathology, Churchill Hospital, Oxford

VALERIE J HOWES, $\mathrm{MB}, \mathrm{DCH}$, house physician

R G MITCHELL, DM, FRCP, consultant microbiologist

Pneumococci isolated from patients and associates: serotypes and MIC determination

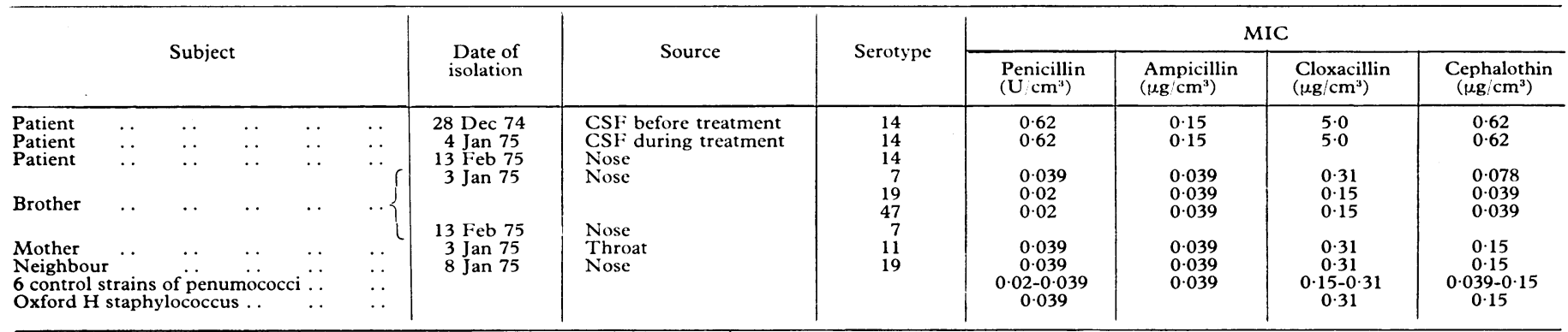

